\title{
Penguatan Daya Saing Umkm O’bite Snack Melalui Strategi Pemasaran Online
}

\author{
Hedi Ajeng Rahayu Putri, Soki Fatmasari \\ Program Studi IImu Administrasi Bisnis, Fakultas IImu Sosial dan Politik, \\ Universitas Yudahrta Pasuruan \\ Email: hediajeng@gmail.com, soqifatmasari@gmail.com
}

\begin{abstract}
Abstrak
Perkembangan UMKM di Indonesia saat ini semakin meningkat. Namun, UMKM di Indonesia memiliki kekurangan, salah satunya dalam hal pemasaran online. Kegiatan ini bertujuan untuk memperkuat daya saing UMKM O'bite Snack. Mitra kami memproduksi dan menjual makanan ringan daei masalah cumi olahan yang dialami oleh mitra kami, yaitu dalam hal pemasaran, pemasaran yang diterapkan hanya dengan metode offline, sedangkan dari aspek SDM, kurangnya pengetahuan tentang situs web. Metode pelaksanaan kegiatan adalah dengan mengadakan pelatihan dan membuat website bagi mitra yang menjual dengan metode online. Hasil dari kegiatan ini adalah bahwa mitra memiliki akun situs web, menyediakan mesin penyegel untuk proses pengemasan dan membuat tata letak yang menarik dengan ditampilkan di etalase toko.
\end{abstract}

Keyword: Daya saing, UMKM O’bite Snack, pemasaran.

\begin{abstract}
The development of MSMEs in Indonesia is currently increasing. However, MSMEs in Indonesia have shortcomings, one of which is in terms of online marketing. This activity aims to strengthen the competitiveness of MSMEs O'bite Snack. Our partners produce and sell snacks daei processed squid problems experienced by our partners, namely in terms of marketing, marketing applied only by offline methods, while from the HR aspect, lack of knowledge about the website. The method of implementation of activities is by conducting training and creating a website for partners selling with online methods. The result of this activity is that the partner has a website account, providing impulse sealer machines for the process of packaging and creating attractive layouts by displaying in storefronts.
\end{abstract}

Keywords: Competitiveness, MSME O'bite Snack, marketing

\section{PENDAHULUAN}

Sidoarjo merupakan kota yang terletak di Jawa Timur yang memiliki berbagai potensi seperti, perdagangan, usaha kecil atau menengah hingga pariwisata. Nama kota Sidoarjo ini merupakan penyangga kota Surabaya. Ketika wisatawan berlibur ke Surabaya pasti tidak akan lupa untuk singgah di Sidoarjo. Terlebih lagi pasca tragedi lumpur Lapindo kota Sidoarjo semakin terkenal di Indonesia sampai manca negara. Sehingga kota Sidoarjo kini lebih di kenal dengan nama "Kota Lumpur".

http://ejournal.urindo.ac.id/index.php/PAMAS

Article History :

Submitted 06 Januari 2021, Accepted 27 April 2021, Published 30 April 2021 
Di Sidoarjo banyak sekali tempat pariwisata yang menarik untuk di kunjungi, seperti pulau Sarinah dan wisata Bahari Tlocor yang ada di desa Tlocor, pantai Kepiting yang terletak di desa Sawohan, museum Tupu Tantular, Alun-alun dan monumen Sidoarjo yang terletak di pusat kota Sidoarjo. Pariwita yang bernuansa sejarah pun ada, yaitu peninggalan kerajaan Majapahit yang bernama Candi Pari yang terletak di desa Candi Pari Porong Sidoarjo. Menurut Kepala dinas kepemudaan, olah raga dan pariwisata Sidoarjo Djoko Supriadi menjelaskan bahwa objek wisata di Sidoarjo mengalami kenaikan dari 33 menjadi 35 objek wisata.

Ketika wisatawan berlibur tidak lengkap bila tidak mengunjungi pusat oleh-oleh, karena wisatawan pasti ingin membeli oleh-oleh untuk keluarga di rumah. Wisatawan pasti membeli oleh-oleh yang unik dan tidak ada ditempat tinggal mereka. Salah satu produk olahan di Sidoarjo yang unik dan jarang ditemukan adalah snack yang diproduksi dari bahan olahan cumi- cumi yang diproduksi oleh mitra kami O'Bite snack. O'Bite snack dapat ditemukan di pusat oleh-oleh di daerah Sidoarjo. Produk yang di produksi oleh mitra kami ini dikerjakan secara manual dari proses pembuatan hingga pengemasan. Proses pembuatan masih menggunakan alat-alat sederhana yang dioperasikan dengan tangan. Kemasannya pun menggunakan bahan plastik yang ditempeli satu persatu dengan stiker nama produk, yang kemudian direkatkan atau dipress menggunakan lilin.

\subsection{Permasalahn Mitra}

\section{a. Permasalahan dari sisi produksi}

1. Proses produksi masih dilakukan dengan cara manual dari tahap pembuatan hingga proses pengemasan sehingga membutuhkan waktu yang lama.

2. Proses produksi masih berbasis pesanan saja, jadi barang tidak selalu tersedia dirumah owner.

3. Dalam pencatuman tanggal produksi dan tanggal expired, mitra terkadang tidak melengkapinya. Jadi informasi mengenai kode ini bagi pelanggan masih belum memenuhi standart.

4. Dalam proses pengemasan mitra menggunakan media lilin untuk mengepres plastik, jadi proses penyimpanan produk kurang terjamin karena wadah mudah terbuka sehingga kualitas produk kurang terjamin. 


\section{b. Permasalahan dari sisi manjemen}

1. Manajemen Pemasaran

a. Mitra kurang bisa memandang dan memanfaatkan peluang pasar yang ada, karena pemasaran mereka hanya menggunakan metode pemasaran offline saja dengan sistem konsinyasi ke toko dan pusat oleh-oleh daerah sekitar.

b. Belum adanya program promosi yang menarik guna memperkenalkan produk ke konsumen dalam skala wilayah yang luas. Promosi selama ini hanya dilakukan dengan metode "mulut ke mulut" sehingga produk hanya dikenal di daerah sekitar saja.

c. Belum adanya program promosi penjualan yang menarik bagi para konsumen, seperti: diskon atau hadiah bagi pelanggan yang membeli dalam jumlah banyak.

2. Manajemen Keuangan

a. Kurangnya kesadaran mitra dalam mengelola modal usaha, sehingga modal yang seharusnya digunakan untuk biaya produksi digunakan juga untuk biaya sehari-hari atau biaya pribadi mitra kami.

b. Tidak adanya pencatatan secara rinci mengenai biaya pengeluaran yang digunakan untuk produksi dan biaya pemasukan dari penjualan produk. Sehingga pengeluaran dan pemasukan harian atau bulanan tidak tercatat secara rinci jadi, untuk menghitung berapa laba yang didapat mitra kurang mengetahui pasti jumlahnya.

3. Manajemen MSDM

a. Kurangnya pengetahuan tentang teknologi informasi (website, instragram, facebook dan Shopee), sehingga SDM yang di miliki tidak bisa mengoperasikannya.

b. Sulitnya memberikan arahan tentang pengoperasian website karena kendala rendahnya latar belakang pendidikan dan faktor usia.

c. Mitra tidak memiliki SDM yang sesuai terutama dari segi pendidikan untuk mengisi posisi sebagai admin yang mengoperasikan website, sedangkan SDM yang dimiliki saat ini tidak bisa mengoperasikan website. 
4. Manajemen Persediaan

a. Tidak adanya buku catatan mengenai persediaan bahan baku atau kartu stock, sehingga sering kali bahan baku habis ketika di butuhkan saat proses produksi. Karena kurangnya pengontrolan mutasi pada bahan baku pada waktu pengambilan bahan baku digudang.

b. Buku stock atau kartu stock untuk produk jadi pun tidak ada. Sehingga, stock produk jadi, stock penambahan produk dan keluarnya produk, mitra tidak melakukan pengotrolan dengan jelas dan rinci.

c. Belum adanya tempat seperti etalase atau rak untuk menata produk-produk yang sudah di kemasa dan siap jual agar lebih menarik dan rapi.

\subsection{Permasalahn yang di prioritaskan}

\section{Aspek Produksi}

a. Pelatihan menggunakan alat impulse sealer guna mempermudah saat proses pengemasan.

\section{Aspek Manajemen}

a. Sosialisasi dan pelatihan untuk mengoperasikan website untuk media pemasaran online.

b. Pembuatan akun guna untuk pemasaran online berupa website, instragram, facebook dan shoppee.

c. Melakukan proses penataan tata letak yang menarik untuk produk-produk yang siap jual agar lebih menarik dan rapi kedalam etalase atau rak.

\subsection{Kajian literatur}

Secara umum Usaha Menengah Kecil dan Mikro (UMKM) di Indonesia masih mempunyai berbagai permasalahan baik dari segi produksi, pengelolaan maupun pemasaran (Fisla Wirda, Herizon and Trimardi Putra, 2020). UMKM dapat diartikan sebagai kegiatan ekonomi yang memiliki omset penjualan tahunan paling banyak, yakni Rp1.000.000.000,- dan milik warga negara Indonesia. Pengertian UMKM tidak hanya dijelaskan oleh para ahli saja, namun UMKM juga dijelaskan di undang-undang Indonesia. Pengertian UMKM menurut UU No 20 Tahun 2008 adalah usaha perdagangan yang dikelola oleh perorangan yan merujuk pada 
usaha ekonomi produktif dengan kriteria yang sudah ditetapkan dalam Undang-Undang. UMKM sendiri di bagi menjadi 3 tingakatan antara lain:

1. Usaha Mikro

Usaha yang memiliki kekayaan bersih mencapai Rp 50.000.000,- serta tidak termasuk bangunan dan tanah tempat usaha. Hasil penjualan usaha mikro setiap tahunnnya paling banyak adalah $\mathrm{Rp} 300.000 .000,-$.

2. Usaha Kecil

Usaha ekonomi yang berdiri sendiri baik dimiliki perorangan atau kelompok, serta bukan sebagai badan usaha cabang dari perusahaan utama. Hasil penjualan bisnis setiap tahunnya antara Rp 300.000.000,- sampai paling banyak Rp 2,5.000.000.000,-.

3. Usaha Menengah

Usaha yang bukan cabang atau anak usaha dari perusahaan pusat dengan total kekayan bersihnya sesuai yang sudah diatur dengan peraturan perundang-undangan. Hasil penjualan tahunannya mencapai Rp2,5.000.000,-- milyar sampai Rp 50.000.000.000,-.

Didalam UMKM pasti tidak akan terlepas dari aspek pemasaran. Pemasaran adalah sebagai suatu proses sosial dan managerial yang membuat individu dan kelompok memperoleh apa yang mereka butuhkan dan inginkan lewat penciptaan dan pertukaran timbal balik produk dan nilai dengan orang lain (Philip Kotler dan Amstrong). Sedangkan menurut nurut William J Stanton, pemasaran adalah suatu sistem keseluruhan dari kegiatan-kegiatan usaha yang ditujukan untuk merencanakan, menentukan harga, mempromosikan dan mendistribusi-kan barang dan jasa yang dapat memuaskan kebutuhan baik kepada pembeli maupun pembeli potensial (Swasta dan Irawan, 2003:5). Pesatnya perkembangan teknologi, dunia digital dan internet tentu juga berimbas pada dunia pemasaran. Tren pemasaran di dunia beralih dari yang semula konvensional (offline) menjadi digital (online). Strategi digital marketing ini lebih prospektif karena memungkinkan para calon pelanggan potensial untuk memperoleh segala macam informasi mengenai produk dan bertransaksi melalui internet. Digital marketing adalah kegiatan promosi dan pencarian pasar melalui media digital secara online dengan memanfaatkan berbagai sarana misalnya jejaring sosial. Dunia maya kini tak lagi 
hanya mampu menghubungkan orang dengan perangkat, namun juga orang dengan orang lain di seluruh penjuru dunia (Sulaksono, 2020).

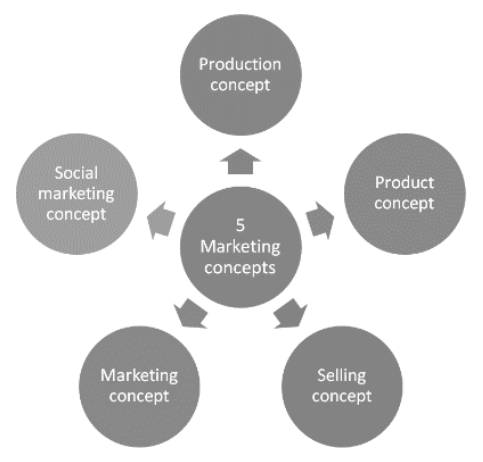

Gambar 1. Grafik konsep pemasaran

Disaat menjalankan sebuah UMKM pasti pelaku usaha mengalami berbagai kendalan dan hambatan berupa suatu masalah. Kendala atau hambatan yang ditemui pelaku usaha merupakan hal lumrah dijumpai oleh semua pelaku bisnis, baik pelaku bisnis kecil maupun besar. Bahkan kendala atau hambatan yang ditemui tergantung besar kecilnya usaha itu sendiri, semakin besar usaha yang dijalankan maka semakin besar dan semakin banyaknya kendala yang ditemui.Kendala atau hambatan bisa ditemui dari segala aspek usaha, bisa ditemui dari segi pemasaran, segi produksi maupun dari segi manajamennya. Pada umumnya permasalahan yang ditemui para pelaku UMKM seperti rendahnya produktivitas, rendahnya SDM yang dimiliki UMKM dalam bidang manajemen, kurangnya keterampilan dalam penguasaan teknologi atau lemahnya UMKM dalam melaksanakan manajemen pemasaran.

\section{METODE}

Kegiatan PKN yang kami lakukan di UMKM O'bite snack yaitu untuk mengumpulkan data-data yang menggunakan metode wawancara dengan pemilik UMKM O'bite snack, observasi dilakukan di tempat produksi dan membuat dokumentasi saat proses produksi dan foto produk. Kami juga melakukan pendekatan dengan metode kualitatif, metode ini menekankan pada data, memanfaatkan teori-teori dari berbagai sumber yang kami gunakan sebagai bahan penjelas yang kemudian kami deskripsikan dalam bentuk kata-kata untuk menyusun jurnal ini. metode yang dilakukan dalam pengabdian ini akan dijelaskan dalam gambar berikut : 


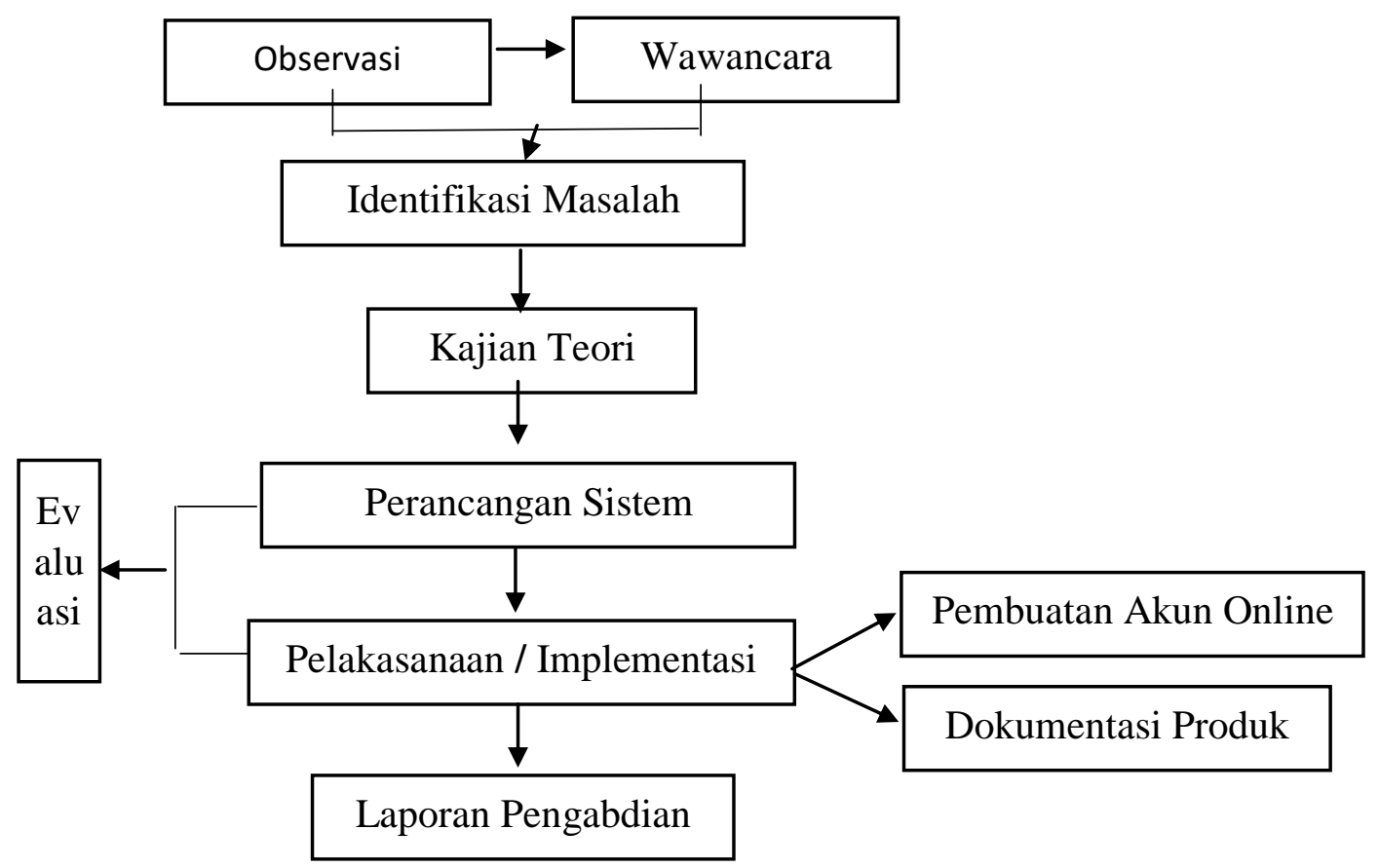

\section{Gambar 2. Prosedur kerja pelaksanaan PKN}

Hal pertama yang dilakukan sebelum pengabdian adalah melakukan observasi dan wawancara kepada pemilik UMKM O'bite Snack. Setelah melakukan observasi, kita dapat mengidentifikasi masalah yang ada pada UMKM tersebut. Setelah mengidentifikasi masalah, kita mengkaji teori yang ada pada UMKM tersebut, materi kajian teori (Refrensi). Setelah mencari bahan kajian teori, kita mulai merancang sistem. Setelah sistem jadi, kita melakukan uji coba, jika dalam uji coba ada yang gagal, maka kita melakukan evaluasi perancangan sistem, jika berhasil maka langsung melanjutkan implementasi. Pelaksanaan implementasi dalam bentuk pembuatan akun online dan dokumentasi produk.Setelah melakukan implementasi, kita menulis laporan pengabdian.
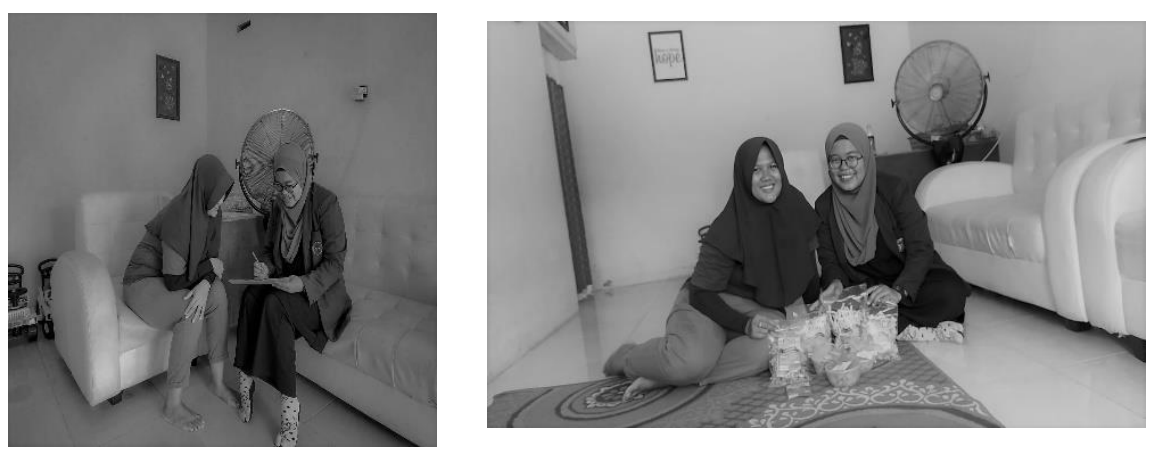

Gambar 7. Wawancara dan Implementasi Kepada Pemilik Usaha O'bite Snack 


\section{HASIL DAN PEMBAHASAN}

Kegiatan PKN yang kami kerjakan berlangsung selama kurang lebih 1 bulan yang dimulai dari awal 1 Desember 2020 sampai dengan 31 Desember 2020. Kegiatan PKN ini kami kerjakan dengan berfokus pada permasalahan pada aspek produksi dan aspek manajemen. Kegiatan awal yang kami kerjakan mulai dari melakukan sesi wawancara dengan owner O'bite snack dan kami juga melakukan diskusi mengenai rencana kami yang akan melakukan pelatihan pembuatan akun pemasaran online berupa website, instragram, facebook dan shopee. Pelaksanaan kegiatan diawali dengan koordinasi dengan owner O'bite Snack. Identifikasi untuk rancangan design website bisnis online dan akun sosial media dari masingmasing usaha. Persiapan design ini akan mewujudkan sebuah website dan akun media sosial yang berfungsi sebagai toko online bagi owner.

Pada pelaksanaan kegiatan pendampingan dilakukan pendampingan dan pelatihan pada owner O'bite Snack, untuk dapat mengoperasionalkan website serta akun- akun sosial media yang telah dibuat. Pada pelaksanaan kegiatan pendampingan dilakukan pendampingan dan pelatihan pada owner O'bite Snack untuk dapat mengoperasionalkan website serta akunakun sosial media yang telah dibuat. Pendampingan dan pelatihan dilakukan dimulai dengan memberikan pengetahuan dan pemahaman dasar-dasar internet marketing hingga sampai owner O'bite Snack mampu melakukan pengelolaan toko onlinenya secara berkelanjutan. Kemudian kami memberikan alat impulse sealer guna mempermudah dan mempercepat proses pengemasan serta kami juga mendisplay dengan rapi dan menarik pada produk yang siap jual ke dalam etalase atau rak.

Adapun rincian-rincian kegiatan yang kami lakukan antara lain:

1. Melakukan sesi wawancara dengan pemilik UMKM O'bite snack, terkait produk-produk yang di produksi yang nanti akan di pasarkan melalaui media online seperti: harga yang ditentukan, promosi atau potongan harga untuk konsumen yang membeli dengan jumlah banyak, dan lain-lain.

2. Kami melakukan sesi diskusi dengan owner O'bite snack mengenai jadwal rencana kami yang akan melakukan pelatihan mengenai akun pemasaran berbasis online.

3. Pelaksanaan pelatihan mengenai website, instragram, facebook dan shoppee sebagai media dalam menjalankan pemasaran online. Dalam pelatihan ini dihadiri oleh 5 orang karyawan dan 2 orang selaku owner dari UMKM O'bite snack. Adapun materi yang kami sampaikan dalam pelatihan ini meliputi: 
a. Pengertian dan kelebihan website, instragram, facebook dan shoppee dalam melakukan strategi pemasaran online.

b. Menjelaskan cara membuat dan mengoperasikan website, instragram, facebook dan shoppee guna memasarkan produk agar lebih banyak lagi konsumen yang mengenal produk yang dijual mitra.

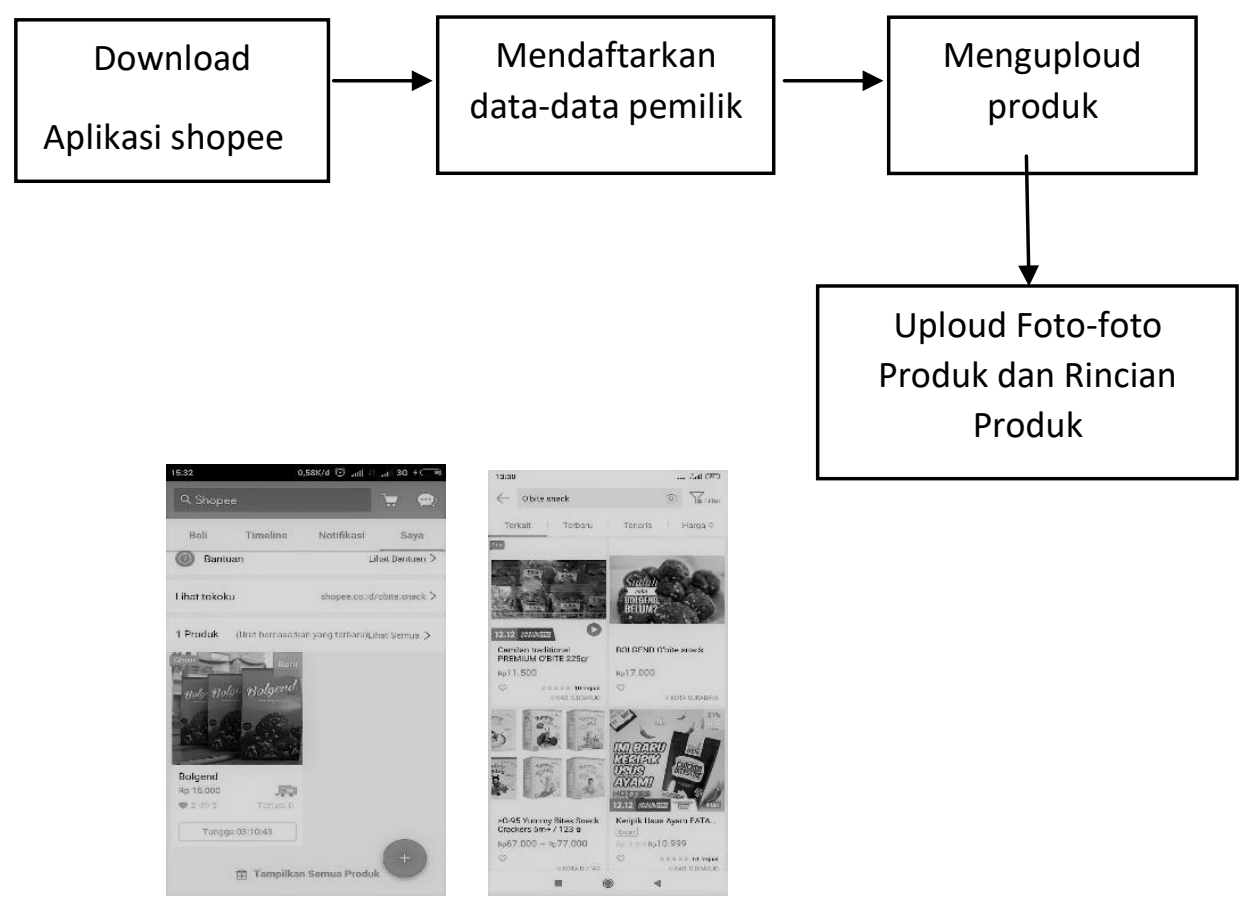

\section{Gambar 3. Prosedur Pendaftaran produk di platform shopee}

Shopee adalah toko online yang berfokus pada pasar mobile. Maka dari itu dalam kegiatan PKN ini kami memberi pelatihan kepada UMKM O'bite Snack menggunakan aplikasi shopee yang dapat digunakan untuk membeli dan menjual barangnya melalui aplikasi shopee. Aplikasi shopee sangat mudah digunakan untuk berjualan secara online dan terdapat banyak peminat dari konsumen di seluruh Indonesia. Tidak seperti aplikasi toko online lainnya, pada aplikasi ini terdapat fitur live chat, dalam hal ini jika penjual setuju bahwa harga dapat langsung diubah sesuai kesepakatan, penjual dapat menggunakan fitur ini untuk melakukan tawar-menawar antara pembeli. Selain itu, penjual dapat menggunakan fitur ini untuk mengajukan pertanyaan lain, seperti ketersediaan produk dan apakah masih seperti saat anda mengobrol di aplikasi pesan instan. 


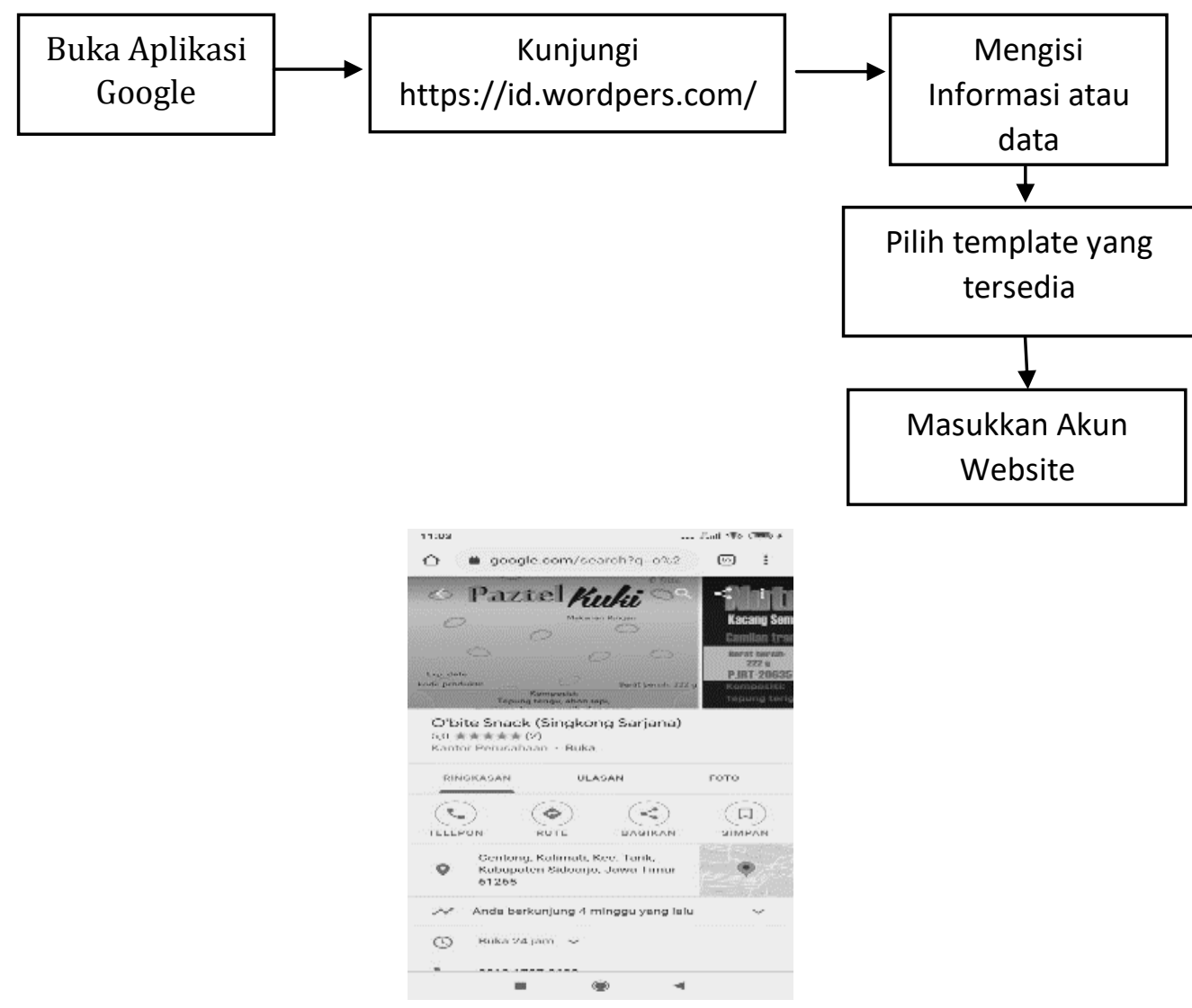

\section{Gambar 4. Prosedur pendaftaran website produk O'bite Snack menggunakan wordpers}

Wordpers adalah platform pembuatan website secara gratis dan populer. Maka dari itu dalam kegiatan PKN ini kami memberikan pelatihan kepada UMKM O'bite Snack agar dapat mendaftarkan produknya melalui website supaya konsumen lebih mudah menemukan toko atau produk secara online, akun wordpers ini juga dilengkapi dengan google map, nomer telepon, sehingga konsumen tidak kebingungan jika berkunjung ke toko secara langsung. Sangat mudah dan praktis untuk digunakan dalam memperluas pemasaran bisnis UMKM O’bite Snack. 


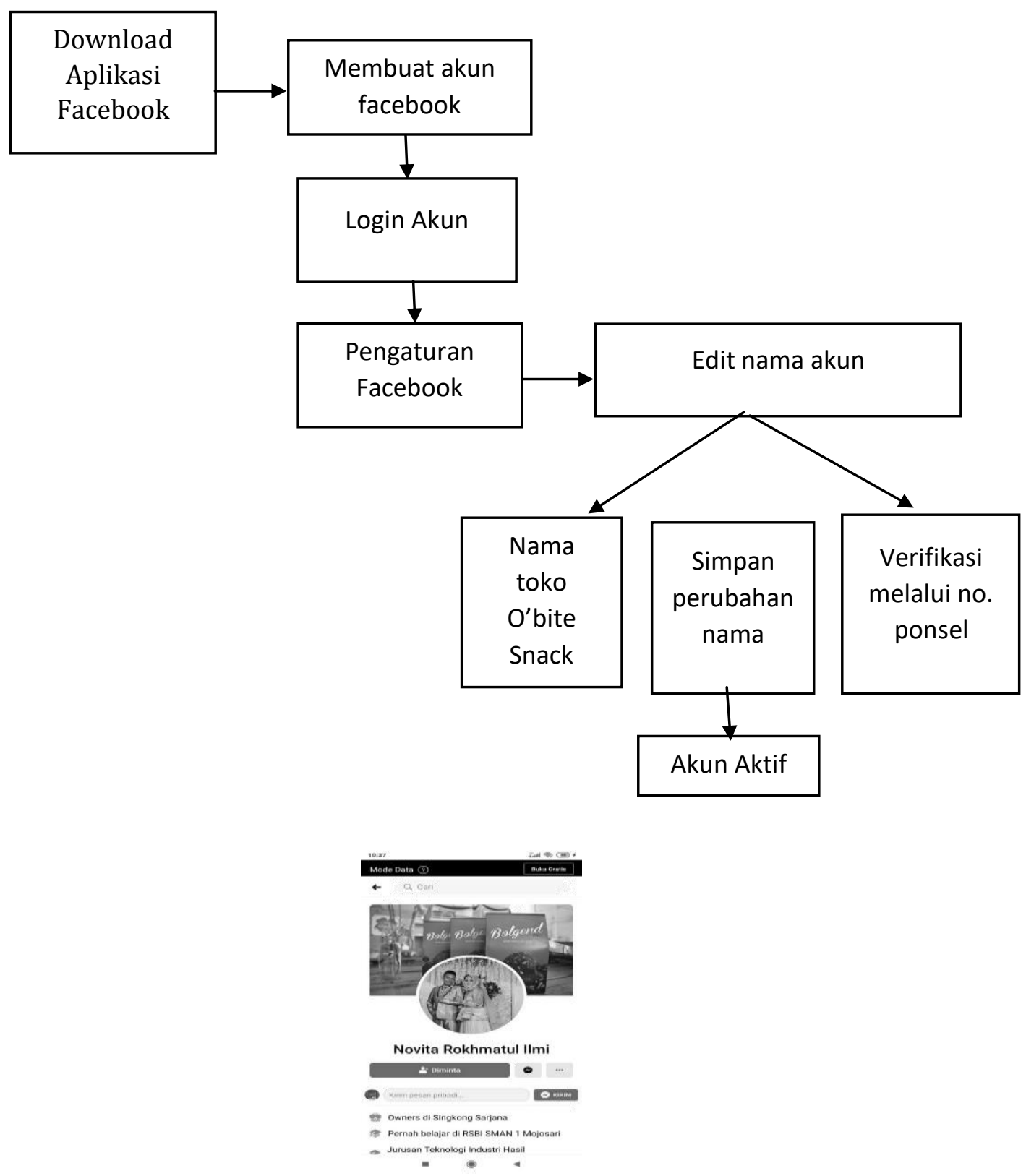

Gambar 5. Prosedur cara membuat akun facebook untuk marketplace

Facebook marketplace adalah fitur jual beli online yang disediakan oleh facebook untuk mengakomodir penggunanya agar bisa melakukan transaksi jual beli. Maka dari itu dalam kegiatan PKN ini kami memberikan pelatihan kepada UMKM O'bite Snack agar dapat mendaftarkan produknya melalui akun facebook marketplace. 


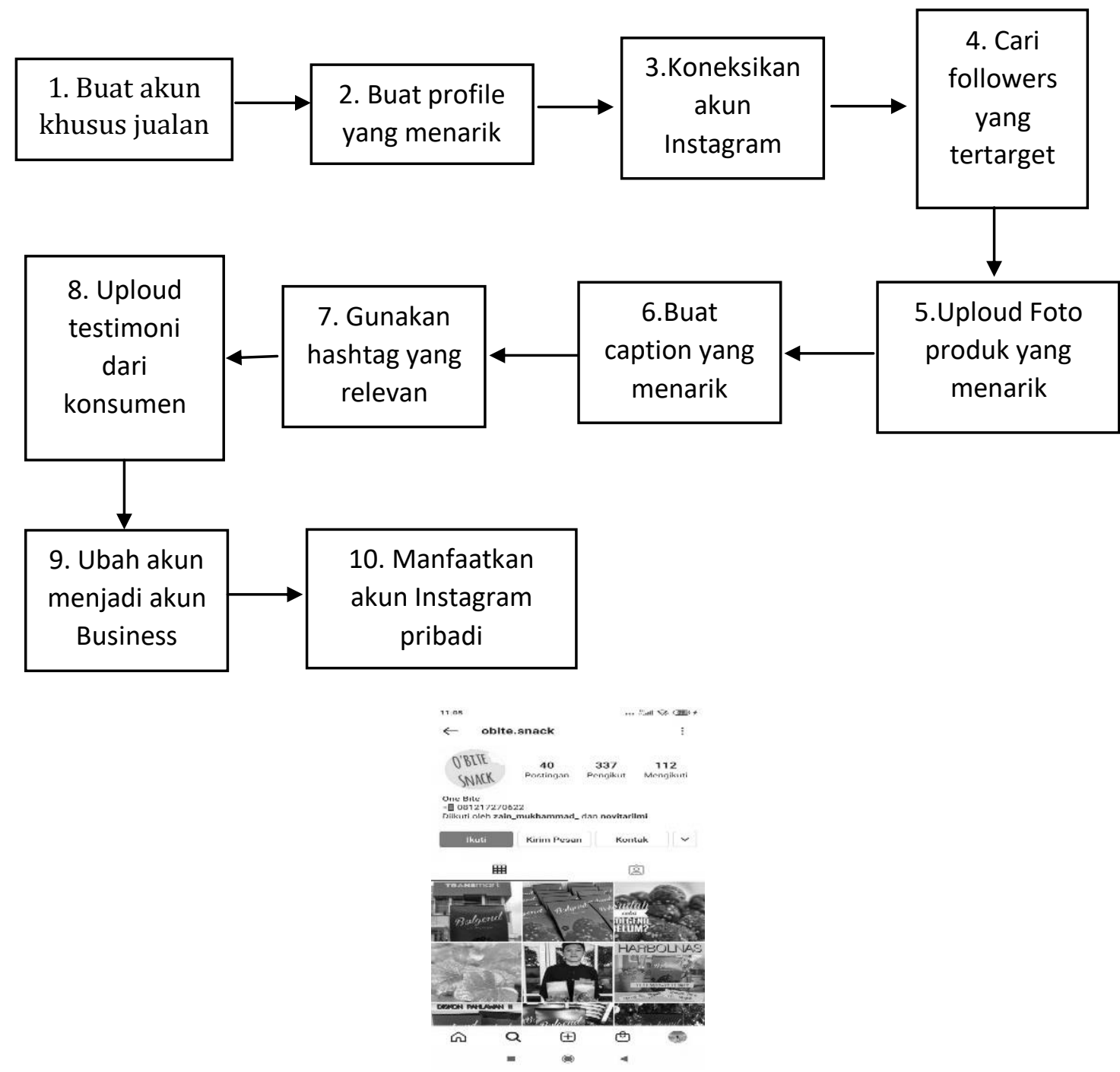

Gambar 6. Prosedur cara pembuatan akun Instagram untuk marketplace

Memulai jualan online di Instagram tidaklah sesulit yang dibayangkan, terutama bagi yang masih enggan atau takut mencobanya karena dianggap rumit, sulit, dan tidak mudah. Seiring dengan semakin meningkatnya jumlah pengguna Instagram, akan sangat disayangkan apabila anda melewatkan kesempatan untuk menawarkan produk atau layanan di dalamnya begitu saja. Instagram sendiri telah terbukti berhasil dan memberikan kesuksesan bagi banyak olshop yang bermain di dalamnya, dan pada kegiatan PKN kali ini akan kami berikan bagaimana cara mudah memulai jualan online di Instagram tersebut. 


\section{KESIMPULAN}

UMKM merupakan salah satu bentuk usaha yang bisa membantu masyarakat dalam memperbaiki kestabilan ekonomi dan mengurangi tingkat pengangguran dikalangan masyarakat. UMKM juga sangat berpengaruh bagi negara karena UMKM memberikan pemasukan devisa bagi suatu negara. Namun, banyak sekali UMKM yang berdiri dan verkembang dengan hambatan atau permasalahan yang sangat berpengaruh bagi kemajuan UMKM itu sendiri. Hambatan-hambatan yang dapat di temukan pun umumnya berasal dari aspek manajemen SDM, manajemen pemasaran bahkan sampai permasalahan dari segi modal. Pemerintah selama ini kurang dalam memberikan bantuan untuk UMKM yang kecil. Tidak ada yang memberikan bimbinga ataupun arahan bagi pelaku UMKM tentang pentingnya manajemen bagi sebuah usaha. Oleh karena itu, banyak sekali UMKM yang berjalan dengan mengikuti alurnya begitu saja. Mereka kurang memahami pentingnya manajemen pemasaran, MSDM bahkan sampai manajemen akuntansi. Sehingga banyak sekali pelaku usaha yang menjalankan usaha dengan sistem asal laku tanpa mengetahui laba yang didapat dan akhirnya berpengaruh dengan modal untuk menjalankan bisnis dikemudian hari. Dalam kegiatan PKN ini, kami menjumpai salah satu UMKM yang memiliki permasalahan umum tersebut. Kami berusaha mengatasi permasalahan yang dialami oleh mitra kami dengan memberikan solusi pemasaran berbasis online. Kami berharap produk dari mitra kami, dapat dikenal oleh konsumen dari luar Sidoarjo. Tujuan kami dengan memberikan solusi pemasaran online ini, agar produk dari owner kami dapat bersaing dipasaran. Kami juga memberikan pembekalan untuk mewujudkan solusi kami dengan memberikan pelatihan mengenai website untuk pemasaran online, agar SDM yang dimiliki oleh mitra kami memiliki keahlian yang positif untuk kemajuan usaha mitra kami.

\section{DAFTAR PUSTAKA}

Fisla Wirda, Herizon and Trimardi Putra (2020) 'Penguatan Daya Saing UKM Pada Usaha Makanan Khas Daerah Sumatera Barat', Dinamisia: Jurnal Pengabdian Kepada Masyarakat, 4(4), pp. 579-587. doi: 10.31849/dinamisia.v4i4.4165.

Sulaksono, J. (2020) 'Peranan Digital Marketing Bagi Usaha Mikro, Kecil, Dan Menengah (Umkm) Desa Tales Kabupaten Kediri', Generation Journal, 4(1), pp. 41-47. doi: 10.29407/gj.v4i1.13906. 
Anugrah, R. J. (2020) 'Efektifitas penerapan strategi online marketing oleh umkm dalam masa pembatasan sosial berskala besar (psbb) corona viruses disease 2019 (covid-19)', Manova, 2(2), pp. 55-65.

Eko, O. et al. (no date) 'Strategi Pemasaran Online Shop Melalui Media Sosial Instagram ( Studi Kasus Akun Instagram Yellowsholic )', pp. 35-52.

Putri, N. A. (2016) 'Desain Strategi Pemasaran Online Pada Fullus Fashion', Jurnal Manajemen dan Start-Up Bisnis, 1(1), pp. 118-127.

Setiawati, I. (2017) 'Pengaruh Strategi Pemasaran Online Terhadap Peningkatan Laba Umkm', Strategi Komunikasi pemasaran, (20), pp. 1-5.

Sulaksono, J. (2020) 'Peranan Digital Marketing Bagi Usaha Mikro, Kecil, Dan Menengah (Umkm) Desa Tales Kabupaten Kediri', Generation Journal, 4(1), pp. 41-47. doi: 10.29407/gj.v4i1.13906.

Technische Universtität München, L.-M.-U. M. (2018) ', e-conversion - Proposal for a Cluster of Excellence, 3, pp. 71-78. 